increased the number of pages by $r$ ro and the figures by 73. A considerable part of the increase in size is due to an expansion of the section dealing with the nervous system; so far as this results in a more adequate account of the cytology of the neurone and of the other constituents of the nervous system such as neuroglia, this can be welcomed unreservedly, but the addition of a little neuroanatomy, much of which is covered in elementary textbooks of biology, is of doubtful value. Several other chapters have been rewritten, notably that dealing with the cell, which now forms an excellent introduction to modern ideas and methods in cytology. The chapter on the liver has been rewritten and that on the kidney very largely rewritten. Most chapters in fact have received some addition or modification and there is no doubt that the general result has been to improve the text considerably and to bring it into closer relationship with recent advances in histological knowledge and technique. While the illustrations have also been improved, quite a large proportion of the microphotographs are less good than one would expect in a book of this price and standard of production.

It is very satisfactory that the book should have survived the modifications necessary in a second edition without losing any of the excellent qualities of the first. It remains an exceedingly readable and intelligent introduction to the study of histology, and has avoided that dreary and impersonal quality which is so characteristic of most textbooks. It is intended primarily for the undergraduate medical student, and naturally is written from the point of view of undergraduate needs and difficulties. Histology, however, enters very largely into almost all aspects of post-graduate medical work. Most post-graduates find that they need special knowledge in some aspect of the subject, and if they are not already expert histologists the relevant sections of this book will be extremely helpful. No textbook, of course, and certainly not one which is limited to a single volume, can provide the detailed knowledge of specialized aspects or applications which postgraduate work may require. It will nearly always be necessary to consult original papers, and for this the classified lists of references given at the end of each chapter will be of great value.

\section{EXTRASYSTOLES AND ALLIED ARRHYTHMIAS}

By David Scherf, M.D., F.A.C.P., and AdolF Schotr, M.D., M.R.C.S. Pp. xv + 531, with 212 illustrations. London: Wm. Heinemann. 1953. $€ 55 \mathrm{~s}$.

It is an advantage in every subject to have a complete reference book. In this small field here is a book to end all reference books. Every aspect of extrasystoles is covered from the historical and investigative viewpoints to therapy. In fact, it is so full and wordy that it is almost impossible to read more than a short section at a time. One is constantly amazed at the thoroughness of the authors in their task. However, one feels that it can only find a place in the libraries of few specialized centres and many cardiologists may feel that five guineas is too much for even such a complete review of so small a branch of their subject, especially as some of the E.C.G.s are so poorly reproduced.

\section{A HANDBOOK ON CANCER FOR NURSES AND HEALTH VISITORS}

By Ronald W. Raven, O.B.E., F.R.C.S. Pp. viii + ro4, with 21 illustrations. London: Butterworth \& Co. 1953. r2s. 6 d.

This reasonably priced book presents clearly and simply just the information a student nurse needs to know about the important subject of malignancy. A sound introduction is made with a description of a normal cell, before noting its change into an $N$ abnormal one. Study of the disease is taken into $\omega$ the wider field of the care of the sick in their own homes, considering especially the problems of the of chronic sick, and their need of attention by night as $N$ well as by day. The link with the social services is $\frac{1}{\sigma}$ good. Excellent photographs illustrate particular cases.

I recommend the book unreservedly to all student nurses to read in conjunction with general textbooks on medicine and surgery.

\section{INFLUENZA}

By C. H. STUart-Harris, M.D., F.R.C.P. Pp 235, with 94 illustrations. London: Edward Arnold \& Co. 1953. 30s.

Infections of the respiratory tract bulk largely in the catalogue of human illness and perhaps the most $\mathbb{D}$ numerous of these are due to viruses. Yet, for many, knowledge of these conditions is inexact and the label ' $\mathrm{flu}$ ' is attached haphazardly to any seasonal infection. Of recent years there has been much accumulation of knowledge of the epidemiology and laboratory diagnosis of influenza and this book does much to clarify the situation with an up to date account of what is known and what is speculative and of present research into virus infections of the respiratory tract.

The book is divided into two halves, the first half devoted to influenza and the second to other infections of the respiratory tract of virus origin. In the chapters on influenza an unusually good balance $\frac{D}{2}$ is maintained between the clinical aspects of the disease and the pathology and epidemiology. The $\mathrm{N}$ clinical picture is fully described with typical case $\sigma$ histories and there is an informative chapter on the $\mathrm{N}$ pulmonary complications with numerous well re- N produced X-rays. The pathology is discussed both $\sigma$ in man and the experimental animal and the bacteriology reviewed in the light of recent out- $\frac{O}{5}$ breaks. The epidemiology is interestingly pre- $\mathbb{D}$ sented and epidemics in different parts of the world $\stackrel{+}{+}$ are discussed with relation to different virus strains $T$ and to varying mortality and attack rate. There is . 
also a rather specialized chapter on laboratory diagnosis. The second half of the book gives brief accounts of other virus infections of the respiratory tract. There are full chapters on atypical pneumonia and febrile catarrh unassociated with the influenza viruses while further short chapters deal with the common cold, $Q$ fever, psittacosis and P.U.O.

Finally, there is discussion on prevention and treatment of these virus infections with a description of the present state of immunization and chemotherapy.

This book is well reproduced and has up to date references after each chapter. It can be warmly recommended to all those who wish to bring up to date their knowledge of these extremely common respiratory conditions.

\section{A GUIDE TO OBSTETRICS IN GENERAL PRACTICE}

By W. C. W. Nixon, M.D., F.R.C.S., F.R.C.O.G., and E. B. HICKSON, M.R.C.S., L.R.C.P., D.R.C.O.G. Pp. 301, with 35 illustrations. London: Staples Press, Ltd. r 953 . 30s.

Here at long last is a thoroughly practical textbook of obstetrics. Such a book has long been needed for those doctors who are practising obstetrics without any specialist experience. All the frills of obstetric theory are left out. Furthermore, the statements which are so often found in textbooks which are handed down from one edition to the next, and which seldom seem to have any basis in practice, are ignored. A good example of this omission is the fact that I could find no mention of the treatment of extended legs in a breech delivery. Instead, one is asked to leave the baby alone until the umbilicus is showing, which is sound advice.

I particularly like the chapter on the desirability of pregnancy. which answers many questions on the chances of abnormalities occurring.

Included at the end of the book are chapters on the National Health Service, notifications and child adoption.

The book is not lavishly produced, nor are there any illustrations. This no doubt has helped to keep the cost down to 30s., which is cheap for present-day textbooks. It is certainly worth farz more.

T.C.F.E.

\section{THE PRACTICAL MANAGEMENT OF PAIN} IN LABOUR

By W. D. WYLIE, M.A., M.B., M.R.C.P. F.F.A.R.C.S. Pp. xii +148 , with 42 illustra tions. London: Lloyd-Luke, Ltd. $1953 \overrightarrow{\mathrm{D}}$ I8s. $6 \mathrm{~d}$.

This is a comprehensive yet concise book which will be of the greatest use to the anaesthetist, the obstetrician and the general practitioner alike. It iswritten in a very pleasing style with excellent illus $\vec{\omega}$ trations which are well grouped to synchronize with? the text, photographs and illustrations of anaesthetif apparatus occupy a section of their own at the end of the appropriate chapter.

Dr. Wylie speaks with authority as it is obvious to the reader that he has personal knowledge of altw the procedures described.

Despite the title the author has managed to in $-\mathrm{T}$ clude all the important anaesthetic proceduresi associated with obstetrics and the text has been soo arranged that each procedure has been dealt with in? its logical sequence. This, and the high quality of production, makes this book all the more easy tof read.

A.J.H.H.

\section{PATHOLOGY OF TUMOURS}

By R. A. WILlis, D.Sc., M.D., F.R.C9P and Edition. Pp. xiv + I,05 I, with 500 illustra tions. London: Butterworth \& Co. I953 $£ 44$ s.

It is a pleasure to welcome the second edition of this- the most authoritative book on tumours in English. Like the other books by Professor Willis it is written in a clear and forthright style which is most refreshing. The work is based on his own experience and the reader is never left in doubt as to the author's meaning or viewpoint. It is. however, not a book for the ordinary student (pres? or post-graduate) but for the specialist in morbio anatomy.

D.M.P.

\section{NOTICE OF SPECIAL INTEREST TO SUBSCRIBERS: \\ "WHY NOT HAVE YOUR COPIES OF THIS JOURNAL BOUND INTO YEARLY VOLUMES?"}

\begin{abstract}
Arrangements have now been made to have the twelve monthly issues fully bound in dark green pin head cloth, lettered in gilt on spine with name of Journal, Volume Number and year, complete with index at front, 17s. 6d. per Volume, post free. A limited number of out of print journals are available to bind into volumes and make your library complete. Price on application giving details of issues required to complete back volumes.
\end{abstract}

THE

MedICINE

\author{
60 PORTLAND PLACE, LONDON, $W .1$
}

WHY NOT

HAVE YOUR

JOURNALS BOUND? 